\title{
Control of Protein Synthesis in Brine Shrimp Embryos by Repression of Ribosomal Activity ${ }^{1}$
}

\author{
F. L. HUANG ${ }^{2}$ AND A. H. WARNER \\ Department of Biology, University of Windsor, Windsor, Ontario, Canada
}

Received January 24, 1974

\begin{abstract}
Undeveloped encysted embryos of the brine shrimp, Artemia salina, contain a large quantity of metabolically repressed $80 \mathrm{~S}$ ribosomes. These ribosomes appear to be inactive or nonfunctional due to the presence of an inhibitor protein on their $60 \mathrm{~S}$ subunit. During development the inhibitor is released or inactivated and the $80 \mathrm{~S}$ ribosomes and their constituent subunits become fully functional in a poly $(\mathrm{U})$-directed protein-synthesizing system. The inefficiency of most $80 \mathrm{~S}$ ribosomes from undeveloped Artemia embryos appears to be due to their inability to form stable complexes with poly(U) and phe-tRNA in the presence of elongation factor, EF-1. A potent inhibitor of protein synthesis has also been found in the $105,000 \mathrm{~g}$ supernatant fraction from undeveloped Artemia embryos. The exact nature of this inhibitor has not been ascertained but it appears to be a heat-labile protein devoid of RNase and protease activity. It is not known whether this inhibitor is the same as that associated with $60 \mathrm{~S}$ ribosomal subunits of undeveloped cyst ribosomes.
\end{abstract}

Although the state of protein synthesis has been elucidated in great detail, control of protein synthesis, especially during embryonic development, is still not clearly understood. It has been established, however, that the rate of protein synthesis increases several-fold after fertilization in animals due to activation of the proteinsynthesizing process (1-3). In ametabolic embryos such as cysts of the brine shrimp, Artemia salina, protein synthesis and development are quiescent but both events resume rapidly after incubation of fully hydrated cysts at $30^{\circ} \mathrm{C}$ in air (4-7). Brine shrimp cysts are not at the same developmental stage as sea urchin zygotes, but the biochemical events associated with resumption of protein synthesis in brine shrimp embryos are similar to those of

\footnotetext{
'Research supported hy the National Research Council of Canada (Grant A-2909). Part of this report was taken from a dissertation submitted to the Graduate Faculty of the University of Windsor by F.L.H. in partial fulfillment of the requirements for the Doctor of Philosophy degree.

${ }^{2}$ Present address: Department of Zoology, National Taiwan University, Taipei, Taiwan.
}

newly fertilized sea urchins $(7,8)$. For this reason brine shrimp embryos have become a useful developmental system for the study of protein synthesis $(6,7,9-12)$.

Several hypotheses have recently emerged in efforts to explain why unfertilized eggs in contrast with fertilized eggs are virtually inactive in protein synthesis. According to these hypotheses, the rate of polysome formation and, therefore, the developmental process, may be regulated by the availability of functional mRNA $(13,14)$, by the functional state of the ribosome monomers $(8,15-18)$, or by the availability of mRNA-specific initiation factors (19).

Artemia salina embryos, like other embryos, show a direct relationship between polysome content and the rate of development (7). Therefore, we have undertaken a series of investigations using brine shrimp embryos in an attempt to ascertain whether protein synthesis is regulated by the physiological state of the ribosomes, by the availability of functional mRNA's, by highly specific initiation factors, or by a combination of all three parameters. This 
paper deals primarily with the role of $A$. salina ribosomes in the regulation of protein synthesis during development.

\section{MATERIALS AND METHODS \\ Materials}

Encysted embryos of A, salina were obtained from the Utah salterns (Canadian Aquarium Supply, Lt'd, St. Thomas, Ont.). Bovine pancreatic RNase, soybean trypsin inhibitor, and chicken ovomucoid were obtained from Worthington (Freehold, NJ). $\left[{ }^{14} \mathrm{C}\right]$ Phenylalanine $(477 \mathrm{Ci} / \mathrm{mole})$, and liquid scintillation fluors 2,5-diphenyloxazole and 1,4-bis[2-(5phenyloxazolyl)]-benzene were obtained from Amersham/Serle (Toronto, Ont.). Potassium polyuridylate, dithiothreitol, and bovine serum albumin (fraction $\mathrm{V}$ ) were purchased from Calbiochem (La Jolla, CA), whereas creatine phosphate, phosphocreatine kinase, ATP, GTP, and sucrose were obtained from Schwarz/ Mann (Orangeburg, NY). All reagents except the fluors and sucrose were stored at $-20^{\circ} \mathrm{C}$ until needed.

Sephadex G-25 and Sepharose 6B were obtained from Pharmacia (Montreal, Que.) and prepared for chromatography as suggested by the manufacturer. DEAE-cellulose (DE-11, Whatman) was prepared according to Peterson and Sober (20). Nitrocellulose filters (type $\mathrm{B} 6$ ) were obtained from Schleicher and Schuell (Keene, $\mathrm{NH}$ ) and all other chemicals and supplies were obtained from Fisher Scientific (T'oronto, Ont.).

High-speed centrifugation steps were carried out using a Beckman preparative ultracentrifuge (Model L2-65), and radioactivity was determined using a Nuclear-Chicago liquid scintillation spectrophotometer (Mark II).

\section{Methods}

Prepuration of A. salina embryos. Encysted embryos of $A$. salina were hydrated in ice-cold hatch mix for at least $3 \mathrm{hr}(21)$. The cysts were allowed to settle under gravity then washed several times with ice-cold distilled water until all debris had been removed. The cysts were used either directly ( 0 -hr sample) or at various times after incubation at $30^{\circ} \mathrm{C}$. The incubation conditions were as previously described (22).

Preparation of ribosomes from A. salina embryos by ultracentrifugation. Embryos from selected developmental stages were ground by hand in a mortar with Buffer A (Tris-HCl, pH $7.7,50 \mathrm{~mm}$; KCl, $2 \mathrm{~mm}$; $\mathrm{MgCl}_{2}, 10 \mathrm{MM}$; dithiothreitol, $1 \mathrm{~mm}$ ) until no intact embryos remained as judged by microscopic examination. Except where indicated, all treatments were carried out at $0-4^{\circ} \mathrm{C}$. The homogenate was centrifuged at $30,000 \mathrm{~g}$ for $10 \mathrm{~min}$ and the supernatant fluid was passed through a rheesecloth-glass woolcheesecloth filter. The filtrate was centrifuged at $80,000 \mathrm{~g}$ (Beckman rotor $60 \mathrm{Ti}$ ) for $15 \mathrm{~min}$ to remove glycogen and the resulting supernatant fluid was centrifuged at $105,000 \mathrm{~g}$ (same rotor) for $1 \mathrm{hr}$. The sediment obtained was designated as the ribosome fraction and suspended in Buffer B (same as Buffer A except that the $\mathrm{KCl}$ concentration is $50 \mathrm{~mm}$ ) for subsequent use. The $105,000 \mathrm{~g}$ supernatant fluid was chromatographed through a column of Sephadex G-25 $(3.5 \times 50 \mathrm{~cm})$ equilibrated with Buffer $B$, and the uv-absorbing material which eluted in the void volume was retained and designated as the $\mathrm{S}-105$ fraction. (This treatment was used primarily for the purpose of removing the large amount of free nucleotides from the macromolecular fraction).

Purification of ribosomes from A. salina embryos using DEAE-cellulose. This ribosome purification procedure was similar to that described by Dufresne and Igarashi (23) but modified slightly. The ribosome fraction obtained above was incubated in Buffer $\mathrm{C}$ (same as Buffer $\mathrm{A}$ except that the $\mathrm{KCl}$ concentration is $500 \mathrm{~mm}$ and dithiothreitol is omitted) for $30 \mathrm{~min}$ at $0^{\circ} \mathrm{C}$, then diluted to contain $50 \mathrm{~mm} \mathrm{KCl}$ (as in Buffer B). The preparation was applied to a column of DEAE-cellulose $(2.2 \times 20 \mathrm{~cm})$ previously equilibrated with Buffer $\mathrm{B}$ minus dithiothreitol. The column was washed with dithiothreitol-free Buffer B until no uv-absorbing material was detectable in the effluent. The ribosomes were eluted with a linear gradient of $\mathrm{KCl}$ in dithiothreitol-free Buffer B from $0.05 \mathrm{M} \mathrm{KCl}$ $(500 \mathrm{ml})$ to $1.0 \mathrm{M} \mathrm{KCl}(500 \mathrm{ml})$ at a flow rate of $3 \mathrm{ml}$ per minute. The ribosomes that eluted as a sharp peak between 0.28 and $0.35 \mathrm{M} \mathrm{KCl}$ were pooled and concentrated by vacuum dialysis. Finally, the ribosomal preparation was dialyzed for $6 \mathrm{hr}$ against Buffer $\mathrm{B}$ then stored at $-70^{\circ} \mathrm{C}$. Ribosomes purified in this way remain fully active for several weeks.

Purification of A. salina ribosomes by washing with $700 \mathrm{mM} \mathrm{KCl}$. The ribosomes obtained by centrifugation at $105,000 \mathrm{~g}$ were suspended in Buffer D (same as Buffer $\mathrm{A}$ except that the $\mathrm{KCl}$ concentration is 700 mM) and stirred gently for $2 \mathrm{hr}$. The preparation was centrifuged at $105,000 \mathrm{~g}$ for $1 \mathrm{hr}$ to remove glycogen and any undissociated ribosomes and polysomes. The supernatant fluid (containing the ribosomal subunits) was then centrifuged at $113,700 \mathrm{~g}$ (Beckman rotor, $\mathrm{Ti}$ 60 ) for $10 \mathrm{hr}$. The sediment was suspended in Buffer B and any insoluble material was removed by centrifugation at $30,000 \mathrm{~g}$ for $15 \mathrm{~min}$. The ribosomes were either used immediately or stored at $-70^{\circ} \mathrm{C}$ until needed.

Preparation of $40 \mathrm{~S}$ and $60 \mathrm{~S}$ ribosomal subunits. A preparation of ribosomes (45 units, $A_{260}$ ) which had been maintained for $2 \mathrm{hr}$ in Buffer D was layered on 11 $\mathrm{ml}$ of a $15-30 \%$ sucrose gradient prepared in Buffer D. The preparation was centrifuged at $200,000 \mathrm{~g}$ (Beckman rotor, SW41) for $3.5 \mathrm{hr}$ and 10-drop fractions were collected from the hottom of the centrifuge tube. The fractions containing the $40 \mathrm{~S}$ and $60 \mathrm{~S}$ subunits were pooled separately, concentrated by vacuum 
dialysis, dialyzed against Buffer $\mathrm{B}$, then stored at $-70^{\circ} \mathrm{C}$ until needed.

Preparation of $A$. salina protein synthesis inhibitor, elongation factors, and aminoacyl-tRNA synthetases. The S-105 fraction described earlier was chromatographed through a column of Sepharose $6 \mathrm{~B}$ $(2.8 \times 85 \mathrm{~cm})$ using Buffer $\mathrm{E}$ (same as Buffer A except the $\mathrm{KCl}$ concentration is $100 \mathrm{~mm}$ ) as the eluent. This system resolved at least four uv-absorbing peaks, and on the basis of the $A_{260} / A_{280}$ ratio, two fractions (I and II) were evident (see Fig. 1). The aminoacyl-tRNA synthetases and elongation factors (EF-1 and EF-2) were isolated from fraction I as follows. Fraction I was concentrated by vacuum dialysis then incubated in Buffer D for $2 \mathrm{hr}$. The preparation was then layered on a $15-30 \%$ sucrose gradient and centrifuged at $200,000 \mathrm{~g}$ as described above. After centrifugation the top $20 \%$ of the gradient was retained since this fraction was found to contain all the enzymes and factors required for polyphenylalanine synthesis. This fraction is referred to as the S-105 proteins. In addition to this source of enzymes and factors, crude phenylalanyltRNA synthetase was prepared from $A$. salina cysts as described by Bagshaw et al. (24), and the elongation factors, EF-1 and EF-2, were purified from the S-105 fraction of $A$. salina cysts essentially as described by $\mathrm{Li}$ and $\mathrm{Yu}$ (25). (Since this work was carried out, Zasloff and Ochoa (9) have reported a method for the isolation of EF-1 $\left(\mathrm{T}_{1}\right)$ and EF-2 $\left(\mathrm{T}_{2}\right)$ from A. salina cysts and this work should be consulted when working with the brine shrimp.)

Fraction II was found to contain a potent inhibitor of protein synthesis; therefore, it was concentrated by vacuum dialysis and used as the source of inhibitor without further purification.

Preparation of A. salina transfer RNA and $\left[{ }^{4} C\right]$ Phe-tRNA. The total tRNA fraction from $A$. salina cysts was prepared essentially as described by Bagshaw et al. (24). Transfer RNA was deacylated by incubation of $\mathrm{RNA}$ with $1.8 \mathrm{M}$ Tris- $\mathrm{HCl}, \mathrm{pH} 8.2$, at $37^{\circ} \mathrm{C}$ for $1 \mathrm{hr}$, then desalted by filtration through a column of Sephadex G-25 using water as the eluent. In a reaction designed to aminoacylate $t R N A^{\text {phe }}$ the following components were incubated together in $5 \mathrm{ml}$ of Buffer B: ATP, $2.5 \mathrm{~mm}$; creatine phosphate, 2.5 $\mathrm{mm}$; phosphocreatine kinase, $0.5 \mathrm{mg}$; $\left[{ }^{14} \mathrm{C}\right.$ ]phenylalanine, $15 \mu \mathrm{Ci}$; unfractionated cysts tRNA, 100 units $\left(A_{260}\right)$, and partially purified phenylalanyl-tRNA synthetase, $5 \mathrm{mg}$. After $30 \mathrm{~min}$ at $30^{\circ} \mathrm{C}$ the reaction was chilled then shaken with an equal volume of $90 \%$ phenol. The tRNA was precipitated from the aqueous phase with ethanol then purified further by passage through a column of Sephadex G-25 $(3.5 \times 50 \mathrm{~cm})$ in the presence of Buffer B.

Assay of ribosomes from selected stages of development for efficiency in binding $\left[{ }^{14} \mathrm{C}\right]$ Phe-tRNA and in polyphenylalanine synthesis. The reaction mixtures designed to measure the binding of $\left[{ }^{14} \mathrm{C}\right] \mathrm{Phe}$ - $t R N A$ to

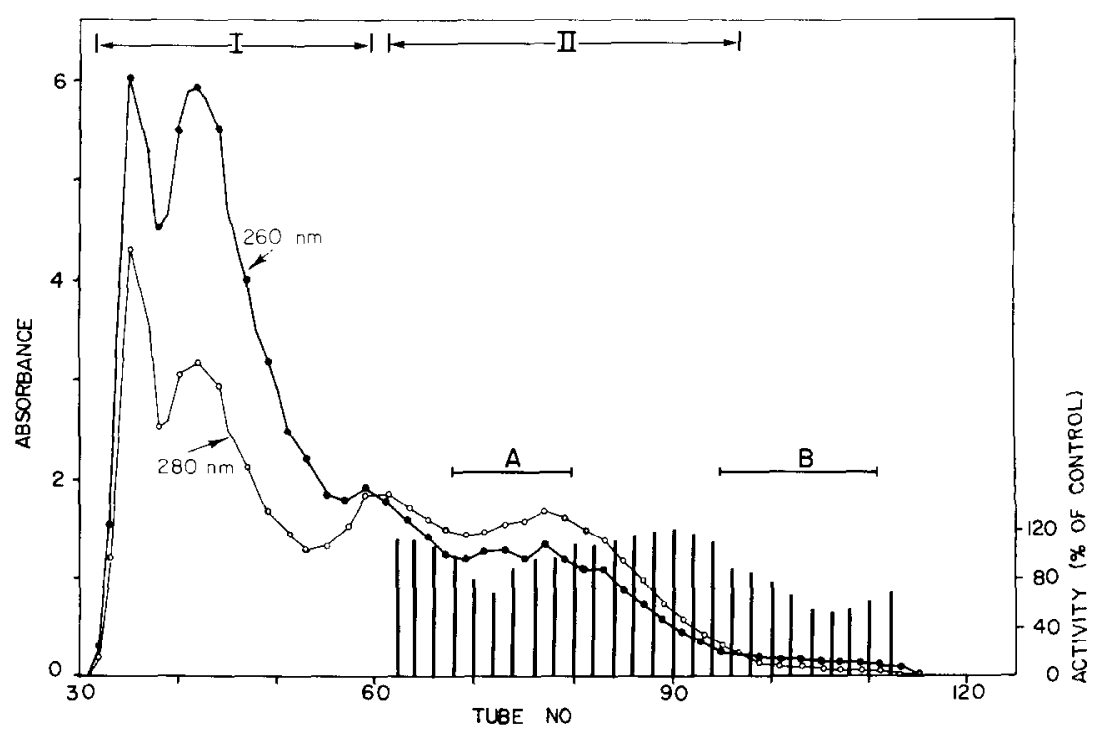

Fig. 1. Chromatography of $A$. salina cyst S-105 fraction on Sepharose 6B. A sample $\left(600 A_{260}\right)$ of the S-105 fraction from 0 -hr cysts was applied to a column of Sepharose $6 B(2.8 \times 85 \mathrm{~cm})$ previously equilibrated with Buffer $\mathbf{E}$. The column was developed with Buffer $\mathrm{E}$ at a flow rate of approximately $50 \mathrm{ml} / \mathrm{hr}$ and 4 -ml fractions were collected. Column fractions $62-112$ were assayed for inhibitory activity in a protein-synthesizing system as described in Table I. These results are shown as the bar graphs. The contents of tubes $32-59$ were pooled, concentrated by vacuum dialysis, and designated as fraction I, whereas the contents of tubes $61-96$ were pooled, concentrated, and designated as fraction II. 
ribosomes contained the following components in $0.125 \mathrm{ml}$ of Buffer B: GTP, $0.8 \mathrm{~mm}$; poly $(\mathrm{U}), 25 \mu \mathrm{g}$; DEAE-cellulose-prepared ribosomes, 2 units $\left(A_{260}\right)$; $\left[{ }^{14} \mathrm{C}\right]$ Phe-tRNA, 5 units $\left(A_{260}\right)$ unfractionated tRNA, $2400 \mathrm{cpm}$; and EF-1, $189 \mu \mathrm{g}$. The reaction mixture was incubated at $30^{\circ} \mathrm{C}$ for $30 \mathrm{~min}$, diluted to $5 \mathrm{ml}$ with ice-cold Buffer $B$, then filtered through a nitrocellulose filter using mild suction. The filter was washed twice with $5 \mathrm{ml}$ of Buffer $\mathrm{B}$, dissolved in $10 \mathrm{ml}$ of scintillation fluid, and counted in a liquid scintillation system as described previously (21). In certain experiments. the effect of elongation factor EF-2 was also determined and in these cases $168 \mu \mathrm{g}$ of EF. 2 was added to the reaction mixture described above for the binding reaction. The reaction was incubated as above then $100 \mu \mathrm{l}$ of the reaction were processed for polypeptide synthesis according to the procedure of Mans and Novelli (26). In all other cases amino acid incorporation into protein was determined as follows. The reaction mixture contained the following in 0.30 $\mathrm{ml}$ of Buffer B: ATP, $2.5 \mathrm{~mm}$; GTP, $1 \mathrm{~mm}$; creatine phosphate, $2.5 \mathrm{~mm}$; phosphocreatine kinase, $30 \mu \mathrm{g}$; poly(U), $100 \mu \mathrm{g}$ except where noted otherwise; $\left[{ }^{14} \mathrm{C}\right.$ ]phenylalanine, $0.25 \mu \mathrm{Ci}$ (sp act $477 \mathrm{Ci} / \mathrm{mole}$ ), ribosomes or ribosomal subunits as indicated in the Tables and Figures; cyst tRNA, 0.75 unit $\left(A_{260}\right)$, and except where otherwise noted, $\mathrm{S}-105$ proteins, $300 \mu \mathrm{g}$. The mixtures were incubated at $30^{\circ} \mathrm{C}$ and at the desired times $50 \mu \mathrm{l}$ were transferred to paper disks (Whatman No. 3) and processed for polypeptide synthesis as described above.

Assay for RNase activity. The amount of RNase in the various fractions was estimated by measuring the amount of acid-soluble nucleotides released from $A$. salina cyst RNA after incubation at $30^{\circ} \mathrm{C}$. The cyst RNA used in these assays was prepared as previously described (22). The RNase assay mixtures were composed of the following in $0.5 \mathrm{ml}$ of Buffer B: cyst RNA, 18 units $\left(A_{260}\right)$, and varying amounts of the fractions to be tested as described in Tables IV and V. The reaction mixtures were incubated at $30^{\circ} \mathrm{C}$ for periods up to $60 \mathrm{~min}$, chilled in an ice-bath, then treated with $1 \mathrm{ml}$ of ice-cold $\mathrm{N} \mathrm{HClO}_{4}$ containing $0.04 \mathrm{M} \mathrm{La}\left(\mathrm{NO}_{3}\right)_{2}$. All fractions treated in this way were maintained at $0^{\circ} \mathrm{C}$ for 15 additional min then centrifuged at $2000 \mathrm{~g}$ for $10 \mathrm{~min}$. Aliquots were taken from the supernatant fluid, diluted with Buffer B then analyzed at $260 \mathrm{~nm}$. One unit of RNse activity is defined as the liberation of 1 unit $\left(A_{260}\right)$ of acid-soluble uv-absorbing material per $30 \mathrm{~min}$ at $30^{\circ} \mathrm{C}$.

Determination of protein and RNA content. Protein was determined according to the method of Lowry et al. (27) using bovine serum albumin as the standard. RNA was estimated according to the method of Ogur and Rosen (28) using A. salina rRNA as the standard, and it was determined that the $40 \mathrm{~S}$ and $60 \mathrm{~S}$ ribosomal subunits contain $44 \mu \mathrm{g}$ and $41 \mu \mathrm{g}$ RNA per unit $\left(A_{260}\right)$, respectively.

\section{RESULTS}

The effect of cyst S-105 fraction on polypeptide synthesis. Our findings confirm previous observations that $80 \mathrm{~S}$ ribosomes or their subunits from encysted embryos of the brine shrimp, A. salina, (0-hr cyst ribosomes) are active in protein synthesis when poly(U) is used as the template $(4-6,9,11)$. In addition, it is now clear that the 0 -hr cyst $105,000 \mathrm{~g}$ supernatant fluid (cyst S-105 fraction) contains both stimulatory as well as inhibitory substances to protein synthesis. Low concentrations of this fraction enhance protein synthesis, whereas high concentrations inhibit protein synthesis (Table I). The stimulatory effect of the S-105 fraction may be due to the addition of enzymes and/or protein factors which are limiting in the $105,000 \mathrm{~g}$ ribosomal sediment, although unwashed ribosomes are able to support protein synthesis extensively in the absence of added S-105 fraction.

When the S-105 fraction was chromatographed on a column of Sepharose 6B, two

TABLE I

The Effect of 0-hr Cyst S-105 Fraction on Incorporation of $\left[{ }^{14} \mathrm{C}\right]$ Phenylalanine into Protein By 0-hr Cyst Ribosomes Using Poly(U) as TEMPLATE ${ }^{a}$

\begin{tabular}{cccc}
\hline $\begin{array}{c}\text { 0-hr cyst } \\
\text { ribosomes }\end{array}$ & $\begin{array}{c}\text { 0-hr cyst } \\
\text { S-105 } \\
\text { fraction } \\
\left.\text { (units } A_{280}\right)\end{array}$ & \multicolumn{2}{c}{ Incorporation (cpm/disk) } \\
\cline { 3 - 4 }+ & - & 30 & 60 \\
+ & 1 & 27054 & 17178 \\
+ & 2 & 23465 & 36331 \\
+ & 4 & 14429 & 15220 \\
+ & 6 & 9137 & 9921 \\
+ & 6 & 4084 & 4443 \\
\hline
\end{tabular}

"The reaction mixture contained the following in $0.3 \mathrm{ml}$ of Buffer B: ATP, $2.5 \mathrm{~mm}$; GTP, $1 \mathrm{~mm}$; creatine phosphate, $2.5 \mathrm{~mm}$; phosphocreatine kinase, $30 \mu \mathrm{g}$; poly(U), $100 \mu \mathrm{g}$; $\left[{ }^{14} \mathrm{C}\right]$ phenylalanine, $0.25 \mu \mathrm{Ci}$; unfractionated cysts tRNA, 1 unit $\left(A_{260}\right)$; ribosomes from $105,000 \mathrm{~g}$ sediment, 4 units $\left(A_{260}\right)$ when added; and $\mathrm{S}-105$ fraction as indicated. One unit $\left(A_{260}\right)$ ribosomes is equivalent to $34 \mu \mathrm{g} R \mathrm{RA}$. The reaction mixtures were incubated at $30^{\circ} \mathrm{C}$ and at the times indicated, 50 $\mu \mathrm{l}$ were transferred to a paper disk and processed for polypeptide synthesis (26). The background value of $100 \mathrm{cpm}$ (0-hr reaction) was subtracted in all cases. 
fractions were obtained on the basis of the $A_{260} / A_{280}$ ratio. Fraction I had an $A_{260} / A_{280}$ ratio greater than 1 , whereas fraction II had a ratio less than 1 (Fig. 1). Fraction I was analyzed further by sucrose gradient centrifugation (after incubation in $700 \mathrm{~mm}$ $\mathrm{KCl}$ ) and found to contain the $40 \mathrm{~S}$ and $60 \mathrm{~S}$ ribosomal subunits and a protein-rich fraction designated as the $\mathrm{S}-105$ proteins near the top of the tube (data not shown). When the fraction I components were tested in a protein-synthesizing system using poly(U) as the template, the data shown in Table II were obtained. We conclude that the S-105 fraction contains the ribosomal components, the initiation and elongation factors, as well as phenylalanyl-tRNA synthetase. In the absence of the $\mathrm{S}-105$ proteins very little polypeptide synthesis occurs. The background activity displayed by the $40 \mathrm{~S}$ and $60 \mathrm{~S}$ subunits is due to cross contamination of these fractions (unpublished observations).

In contrast to the findings described above, fraction II from Sepharose $6 \mathrm{~B}$ (see Fig. 1) was found to contain the inhibitory component(s) of the S-105 fraction. When fraction II was tested in a protein-synthesizing system, it was found to contain a potent inhibitor of protein synthesis. Furthermore, the degree of inhibition is pro-

TABLE II

The Role of S-105 Proteins in Stimulating Polyphenylalanine Synthesis Using Ribosomal SUbunits ${ }^{a}$

\begin{tabular}{c|c|c|r|r|r}
\hline $\begin{array}{c}\text { Ribosomal } \\
\text { subunits }\end{array}$ & $\begin{array}{c}\text { Amount } \\
(\mu \mathrm{g} \text { RNA) }\end{array}$ & \begin{tabular}{c} 
S-105 \\
pro- \\
teins \\
\cline { 4 - 6 }
\end{tabular} & \multicolumn{3}{|c|}{$\begin{array}{c}\text { Incorporation } \\
\text { (cpm/disk) }\end{array}$} \\
\cline { 4 - 6 } & & $\mu \mathrm{g})$ & \multicolumn{2}{|c}{ Time (min) } \\
\cline { 4 - 6 } & & & 10 & 20 & 30 \\
\hline $40 \mathrm{~S}$ & 17.6 & + & 220 & 372 & 524 \\
$60 \mathrm{~S}$ & 28.7 & + & 294 & 850 & 1390 \\
$40 \mathrm{~S}+60 \mathrm{~S}$ & $17.6+28.7$ & - & 112 & 145 & 187 \\
$40 \mathrm{~S}+60 \mathrm{~S}$ & $17.6+28.7$ & + & 1021 & 4603 & 7633 \\
- & - & 1 & 230 & 386 & 454 \\
\hline
\end{tabular}

${ }^{a}$ Except for the ribosomal and S-105 protein additions indicated above, the reaction mixtures and conditions were similar to that described in Table I. The source of ribosomal components and S-105 proteins was from 0 -hr cysts. The hackground value of $100 \mathrm{cpm}(0-\mathrm{hr}$ reaction) was subtracted in all cases. portional to the amount of fraction II added (Table III). In addition, it should be noted that the reconstituted S-105 fraction (line 6, Table III) shows similar activity to the unfractionated S-105 fraction (line 3, Table III). It thus appears that the S-105 fraction from brine shrimp embryos contains ribosomal material and the substances which promote protein synthesis (fraction I) as well as a substance(s) which inhibits protein synthesis (fraction II).

The nature of the inhibitor(s) in the S-105 fraction. Fraction II showed no proteolytic activity but contained some RNase activity. In order to determine whether the RNase activity detected in fraction II was sufficient to account for the protein-synthesis inhibition produced by this fraction, the effect of varying amounts of bovine pancreatic RNase were compared with the effects of fraction II. The results (Table IV) indicate that the inhibitory effect of fraction II on protein synthesis is not due mainly to the RNase in fraction II, but to some other factor(s). Bovine pancreatic RNase at a concentration similar to that found in fraction II showed a much smaller degree of inhibition than did fraction II. For instance, 100 pg of pancreatic RNase has hydrolase activity comparable to that of 2 units $\left(A_{280}\right)$ of fraction II, but inhibits protein synthesis by only $8 \%$ compared to $91 \%$ inhibition for fraction II. In another experiment, tests of aliquants from various Sepharose $6 \mathrm{~B}$ column fractions showed that two regions from the column contained inhibitory material. These findings are illustrated in Fig. 1 by the bar graphs. The first inhibitor (A) elutes in the early region of fraction II with maximal inhibition at tube 72, whereas the second inhibitor (B) elutes primarily beyond the area designated as fraction II with maximal inhibition at tube 106 . When the inhibitors were compared in a protein-synthesizing system the data shown in Table $\mathrm{V}$ were obtained. It is clear that inhibitor $\mathrm{A}$ is more potent than inhibitor $B$ although the latter contains considerable RNase activity. In addition, inhibitor $A$ is thermolabile whereas inhibitor $B$ is thermostable, a finding which is similar to that observed for bovine pancreatic RNase. Inhibitor A is 
TABLE III

The Effect of Sephakose 6B Fractions I and II on Polyphenylalanine Synthesis ${ }^{t t}$

\begin{tabular}{|c|c|c|c|c|c|c|}
\hline \multicolumn{2}{|c|}{$\begin{array}{l}\text { Sepharose } \\
6 \mathrm{~B} \text { fraction }\end{array}$} & \multirow{3}{*}{$\begin{array}{l}\text { Unfrac- } \\
\text { tionated } \\
\text { S-105 } \\
\text { fraction } \\
\text { (units, } \\
A_{260} \text { ) }\end{array}$} & \multirow{2}{*}{\multicolumn{4}{|c|}{$\begin{array}{c}\begin{array}{c}\text { Incorporation } \\
\text { (cpm/disk) }\end{array} \\
\text { Time }(\mathrm{min})\end{array}$}} \\
\hline \multirow{2}{*}{$\begin{array}{l}\text { Frac- } \\
\text { tion I } \\
\left(A_{260}\right)\end{array}$} & \multirow{2}{*}{$\begin{array}{c}\text { Frac- } \\
\text { tion II } \\
\left(A_{280}\right)\end{array}$} & & & & & \\
\hline & & & 15 & 30 & 60 & 90 \\
\hline 6 & - & - & 31677 & 41160 & 41889 & 43144 \\
\hline- & 2.5 & - & 540 & 591 & - & - \\
\hline.- & - & 8 & 3561 & 4084 & 4643 & 4940 \\
\hline 6 & 0.5 & - & 14695 & 16595 & 16567 & 17710 \\
\hline 6 & 1.0 & - & 7268 & 9061 & 9392 & 9472 \\
\hline 6 & 2.0 & - & 3695 & 3836 & 3893 & 3931 \\
\hline 6 & 4.0 & - & 1575 & 1763 & 1825 & 1851 \\
\hline 6 & 6.0 & - & 925 & 949 & 950 & 1065 \\
\hline
\end{tabular}

a The reaction mixtures and conditions were the same as described in Table I. The source of ribosomes and factors was fraction I (see Fig. 1) and this fraction contains $32 \mu \mathrm{g}$ RNA per unit $\left(A_{260}\right)$. The S-105 fraction contains fractions $I$ and II in a ratio of about 3 to 1 . The background value of $100 \mathrm{cpm}(0-\mathrm{hr}$ reaction) was subtracted in all cases.

trypsin sensitive but insensitive to ovomucoid and the soybean trypsin inhibitor. Taken together these observations suggest that the primary inhibitor substance in the embryo (inhibitor A) is a protein but not a general protease or RNase. In contrast, inhibitor B appears to be embryo RNase.

Translational efficiency of ribosomes from various developmental stages. In an earlier study Clegg and Golub reported that the rate of translation of poly(U) was greatest with ribosomes from developing $A$. salina embryos ( $2 \mathrm{hr}$ ) than with ribosomes from unincubated cysts (5). These findings were in disagreement with those of Hultin and Morris who reported that ribosomes from undeveloped and highly developed $A$. salina embryos support polyphenylalanine synthesis to the same extent (6). In an attempt to resolve these differences, ribosomes were isolated from $A$. salina at various stages of development, purified using two methods different from those used previously, then tested for their ability to support polypeptide synthesis using poly(U) as template. When the proteinsynthesizing ability of $A$. salina ribosomes purified by the DEAE-cellulose method was determined, the results shown in Table VI were obtained. These findings indicate that ribosomes from developing embryos synthesize proteins more efficiently than those from undeveloped cysts $(0-\mathrm{hr}$ embryos). Also, it should be noted that the differences in efficiency are manifested more clearly beyond the initial period of protein synthesis $(30-120 \mathrm{~min})$. Furthermore, it should be noted that activity in the absence of added poly $(U)$ also increases with development. This finding is probably due to increasing levels of mRNA associated with the ribosomes (as polysomes) (5, 7). However, the higher efficiency of ribosomes from advanced developmental stages (compared to undeveloped cysts) is not due to increased amounts of endogenous mRNA since mRNA will actually reduce the availability of sites on the ribosome for poly(U) translation despite the fact that the template efficiency of poly $(U)$ is much higher than that of natural mRNA (29). This observation is supported by the fact that RNase treatment of ribosomes from 12-hr $A$. salina embryos

\section{TABLE IV}

A Cumparison uf Serharose 6 B Fraction II and Bovine Pancreatic RNase on an A. salina CyST Protein-Synthesizing System ${ }^{a}$

\begin{tabular}{lrrrr}
\hline $\begin{array}{c}\text { Source of } \\
\text { RNase }\end{array}$ & $\begin{array}{c}\text { Amount } \\
\text { added }\end{array}$ & $\begin{array}{c}\text { Units of } \\
\text { activity }\end{array}$ & $\begin{array}{c}\text { Incor- } \\
\text { poration } \\
\text { (cpm/ } \\
\text { disk) }\end{array}$ & $\begin{array}{c}\text { Inhibi- } \\
\text { tion } \\
(\%)\end{array}$ \\
\hline- & - & - & 41160 & 0 \\
Bovine & $1 \mathrm{pg}$ & 0.180 & 41138 & 0 \\
Bovine & $10 \mathrm{pg}$ & 0.279 & 40735 & 2 \\
Bovine & $100 \mathrm{pg}$ & 0.789 & 38481 & 8 \\
Bovine & $1000 \mathrm{pg}$ & 3.870 & 19645 & 53 \\
Fraction II & $0.5 A_{280}$ & 0.243 & 16595 & 60 \\
Fraction II & $1.0 A_{280}$ & 0.490 & 9061 & 78 \\
Fraction II & $2.0 A_{280}$ & 0.832 & 3836 & 91 \\
Fraction II & $4.0 A_{280}$ & 1.210 & 1763 & 96 \\
Fraction II & $6.0 A_{280}$ & 1.507 & 949 & 98 \\
\hline
\end{tabular}

The source of ribosomes and factors was the S-105 fraction $I$ and 6 units $\left(A_{260}\right)$ were used in each reaction. The reaction mixtures and conditions were as described in Table I, except that the reaction was terminated at $30 \mathrm{~min}$.

"One unit of RNase activity is defined as the liberation of 1 unit $\left(A_{260}\right.$ ) of acid-soluble uv-absorbing material per $30 \mathrm{~min}$ at $30^{\circ} \mathrm{C}$ using $A$. salina $\mathrm{RNA}$ as substrate. 
TABLE V

The Effect or the S-105 Fraction Inhibitors on Polyphenylalanine Synthesis ${ }^{a}$

\begin{tabular}{|c|c|c|c|c|c|c|c|c|}
\hline \multirow[t]{3}{*}{ Substance } & \multirow[t]{3}{*}{ Amount } & \multirow{3}{*}{$\begin{array}{l}\text { RNase } \\
\text { activity }^{b} \\
\text { (units) }\end{array}$} & \multirow{3}{*}{$\begin{array}{l}\text { Heat } \\
\text { treat- } \\
\text { ment }^{c}\end{array}$} & \multirow{3}{*}{$\begin{array}{c}\text { Trypsin } \\
\text { treat- } \\
\text { ment }^{d}\end{array}$} & \multirow{3}{*}{$\begin{array}{c}\text { Trypsin } \\
\text { inhibitor } \\
(25 \mu \mathrm{g})\end{array}$} & \multirow{2}{*}{\multicolumn{3}{|c|}{$\frac{\text { Incorporation }(\mathrm{cpm} / \text { disk })}{\text { Time }(\mathrm{min})}$}} \\
\hline & & & & & & & & \\
\hline & & & & & & 30 & 60 & 90 \\
\hline No addition & - & - & - & - & - & 5461 & 10467 & 14433 \\
\hline Inhibitor A & $0.1 A_{280}$ & Trace & - & - & - & 2026 & 3298 & 3973 \\
\hline Inhibitor $\Lambda$ & $0.1 A_{280}$ & Trace & + & - & - & 4368 & 7536 & 10103 \\
\hline Inhibitor A & $0.1 A_{28 \mathrm{O}}$ & Trace & - & + & Ovomucoid & 3488 & 6852 & 8774 \\
\hline Inhibitor A & $0.1 A_{280}$ & Trace & - & - & Ovomucoid & 1823 & 2968 & 3575 \\
\hline Inhibitor A & $0.1 A_{280}$ & Trace & - & - & Soybean & 1985 & 3232 & 3858 \\
\hline Inhibitor B & $0.1 A_{280}$ & 0.24 & - & - & - & 3931 & 7536 & 8659 \\
\hline Inhibitor B & $0.1 A_{280}$ & 0.24 & + & - & - & 4013 & 7587 & 8693 \\
\hline Bovine RNase & $0.01 \mu \mathrm{g}$ & 1.2 & - & - & - & 6334 & 10042 & 11835 \\
\hline Bovine RNase & $0.20 \mu \mathrm{g}$ & 21.6 & - & - & - & 294 & 321 & 355 \\
\hline Bovine RNase & $0.20 \mu \mathrm{g}$ & 21.6 & + & - & - & 365 & 479 & 528 \\
\hline
\end{tabular}

${ }^{a}$ The reaction mixtures and conditions were as described in Table I except that the source of ribosomes and factors was the S-105 fraction I ( 0.75 unit $\left.A_{280}\right)$. See also Table III. The background value $(0$-hr reaction) was subtracted in all cases.

${ }^{b}$ As described in Table IV.

' Inhibitor A and $\mathrm{B}$ and bovine RNase were heated at $70^{\circ} \mathrm{C}$ for $15 \mathrm{~min}$.

${ }^{a}$ Inhibitor A (20 units $A_{280}$ ) was treated with $50 \mu \mathrm{g}$ of trypsin in Buffer B for $15 \mathrm{~min}$ at $30^{\circ} \mathrm{C}$ then $1 \mathrm{mg}$ of chicken ovomucoid was added. The mixture was dialyzed for $6 \mathrm{hr}$ against Buffer $B$ then an aliquot was added to the reaction mixture as indicated.

enhances the ability of these ribosomes to translate poly(U) while the endogenous protein-synthesizing activity is lowered considerably (30). There appears to be an inverse relationship between the amount of endogenous mRNA and the efficiency of ribosomes to translate poly(U).

When $\mathrm{KCl}$-washed ribosomes were tested in a poly(U)-directed protein-synthesizing system results similar to those obtained using DEAE-cellulose prepared ribosomes were observed (see Tables VI and VIII). Although the increase in ribosomal efficiency observed by this method of preparation is not as great as that found using ribosomes purified by the DEAE-cellulose method, these ribosomes are similar to those prepared by the latter method in their reponse to S-105 proteins, in the extent of endogenous activity, and in the marked increase in translational efficiency of brine shrimp ribosomes with development.

The binding of $\left[{ }^{14} \mathrm{C}\right]$ Phe-tRNA to ribosomes from different stages of development. Since ribosomes from undeveloped A. salina cysts are inefficient in poly- peptide synthesis when compared with ribosomes from developing embryos, we attempted to ascertain whether the ribosomes themselves were actively repressed, or whether some important protein factor(s) is (are) missing from the S-105 fraction used as the enzyme source. To test for the ability of $A$. salina ribosomes to bind $\left[{ }^{14} \mathrm{C}\right] \mathrm{Phe}$-tRNA in the presence of poly(U), the elongation factor EF-1 was isolated from brine shrimp cysts (see Methods) and tested using ribosomes from different stages of development. The results of this experiment are shown in Table VII. From these results it can be seen that the binding efficiency of ribosomes increases as development proceeds. It may be argued, however, that the "observed" binding activities catalyzed by EF-1 are higher when ribosomes from advanced stages are used rather than from undeveloped cysts since peptide chain elongation (protein synthesis) is also occurring as a result of contamination of EF-1 with factor EF-2 (a protein factor required for chain elongation). That this is not the case is also shown in Table VII. Only when EF'-2 was added did appre- 
ciable polypeptide synthesis occur. We conclude, therefore, that the binding activity catalyzed by EF-1 is due primarily to the binding of $\left[{ }^{14} \mathrm{C}\right] \mathrm{Phe}-\mathrm{tRNA}$ to the poly(U)-ribosome complex, and that the binding efficiency is a function of the developmental age of the embryo. In addition, these data are consistent with the idea that the low efficiency of 0 -hr embryo ribosomes in support of protein synthesis may be due to functionally defective ribosomes in these embryos.

Translational efficiency of ribosomal subunits from $0-h r$ and 12-hr embryos. In an attempt to ascertain whether the ribosomal subunits from $A$. salina cysts are defective or unable to interact normally during formation of the initiation complex, ribosomes were isolated by centrifugation from 0 -hr and 12 -hr embryos and treated as follows. One batch (the controls) of ribosomes from 0 -hr and $12-\mathrm{hr}$ embryos was incubated in Buffer D (to dissociate the

TABLE VI

A Comparison of Ribosomal Activity from Different Developmental Stages of A. salina EMBRYOS $^{a}$

\begin{tabular}{|c|c|c|c|c|c|}
\hline \multirow{3}{*}{$\begin{array}{l}\text { Source of } \\
\text { ribosomes }\end{array}$} & \multirow{3}{*}{$\begin{array}{l}\text { Poly(U) } \\
(100 \mu \mathrm{g})\end{array}$} & \multicolumn{4}{|c|}{ Incorporation (cpm/disk) } \\
\hline & & \multicolumn{4}{|c|}{ Time (min) } \\
\hline & & 15 & 30 & 60 & 120 \\
\hline 0 -Hr embryos & + & 1826 & 2880 & 3972 & 4142 \\
\hline $0-\mathrm{Hr}$ embryos & - & 200 & 345 & 470 & 370 \\
\hline 1-Hr embryos & + & 4014 & 8260 & 12350 & 14300 \\
\hline 1-Hr embryos & - & 580 & 720 & 1290 & 1735 \\
\hline 3-Hr embryos & + & 2940 & 6450 & 10300 & 12800 \\
\hline 3-Hr embryos & - & 310 & 630 & 1310 & 2200 \\
\hline 6-Hr embryos & + & 4590 & 9800 & 14630 & 17800 \\
\hline 6-Hr embryos & - & 420 & 915 & 1650 & 2475 \\
\hline 12-Hr embryos & + & 7000 & 16360 & 25600 & 31360 \\
\hline 12-Hr embryos & - & 450 & 928 & 1750 & 2720 \\
\hline
\end{tabular}

a The ribosomes were prepared by DEAE-cellulose chromatography and 4 units $\left(A_{260}\right)$ were used in each reaction. The $\mathrm{S}-105$ proteins $(300 \mu \mathrm{g}$ per reaction mixture) were from 0 -hr cysts. Otherwise the reaction mixtures and conditions were the same as described in Table I. The background value of $100 \mathrm{cpm}(0-\mathrm{hr}$ reaction) was subtracted in all cases.
TABLE VII

The Binding of $\left[{ }^{14} \mathrm{C}\right]$ Phe-tRNA to Ribosomes and IncoRporation of $\left[{ }^{14} \mathrm{C}\right]$ Phe into Polyphenylalanine Catalyzed by Elongation Factors EF-1 and EF-2 $2^{a}$

\begin{tabular}{|c|c|c|c|c|}
\hline \multirow[t]{2}{*}{$\begin{array}{l}\text { Source of } \\
\text { ribosomes }\end{array}$} & \multicolumn{2}{|c|}{$\begin{array}{l}\text { Addition of } \\
\text { factors }\end{array}$} & \multirow{2}{*}{$\begin{array}{l}\text { Binding } \\
\text { activity } \\
(\mathrm{cpm})\end{array}$} & \multirow{2}{*}{$\begin{array}{l}\text { Incorpo- } \\
\text { ration } \\
\text { activity } \\
(\mathrm{cpm})\end{array}$} \\
\hline & $\mathrm{EF}-1$ & $\mathrm{EF}-2$ & & \\
\hline 0 -Hr embryos & + & - & 140 & - \\
\hline 1-Hr embryos & + & - & 420 & - \\
\hline 6-Hr embryos & + & - & 690 & - \\
\hline 12-Hr embryos & + & - & 780 & - \\
\hline 12-Hr embryos & - & - & 60 & - \\
\hline $12-\mathrm{Hr}$ embryos & + & - & - & 150 \\
\hline 12-Hr embryos & - & + & - & 110 \\
\hline 12-Hr embryos & + & + & - & 580 \\
\hline
\end{tabular}

a The reaction mixtures and conditions were exactly as described in the Methods.

$80 \mathrm{~S}$ ribosomes into the $40 \mathrm{~S}$ and $60 \mathrm{~S}$ subunits and to release loosely bound ribosomal proteins), then subjected to sucrose gradient centrifugation. Another batch of ribosomes from 0-hr and 12-hr embryos was treated similarly except that the ribosomes were first passed through a column of Sepharose 6B (in Buffer E) then incubated in Buffer $\mathrm{D}$ to dissociate the $80 \mathrm{~S}$ ribosomes. Although the 0 -hr embryo ribosomes are almost completely dissociated into their subunits (40S and $60 \mathrm{~S}$ ) by this treatment, the 12-hr embryo ribosomal preparation, due to the presence of polysomes (7), is more resistant to dissociation. These findings are in accord with others reported previously $(31,32)$. The ribosomal subunits obtained in this way were reconstituted in various combinations, then tested for their ability to support protein synthesis (Table VIII). Reconstituted ribosomal subunits from 0 -hr embryos (control batch) were active in protein synthesis but less active than reconstituted ribosomal subunits from 12-hr embryos prepared in the same way. These findings are consistent with those obtained earlier using unfractionated ribosomes from $0-\mathrm{hr}$ and $12-\mathrm{hr}$ embryos (see Table VI). However, if the ribosomes from 0 -hr and 12 -hr embryos are filtered through Sepharose $6 \mathrm{~B}$ prior to their dissociation into subunits, the recombined subunits from 0 -hr and 12-hr embryos show equal activity in a protein-synthesizing 
TABLE VIII

A Comparison of the Tranglational Efficiencies of Ribosomal Subunits from 0-hr and 12-hr A. salina Embryos Using Poly $(\mathrm{U})$ as Template ${ }^{\prime \prime}$

\begin{tabular}{|c|c|c|c|c|c|c|c|c|c|c|}
\hline \multicolumn{3}{|c|}{$\begin{array}{l}\text { Subunits and } \\
\text { Source }\end{array}$} & \multicolumn{8}{|c|}{ Incorporation (cpm/disk) } \\
\hline \multirow[t]{3}{*}{$40 \mathrm{~S}$} & & \multirow[t]{3}{*}{$60 \mathrm{~S}$} & \multicolumn{4}{|c|}{ Control } & \multicolumn{4}{|c|}{ Sepharose 6B treatment } \\
\hline & & & \multicolumn{2}{|c|}{ Expt $1^{b}$} & \multicolumn{2}{|c|}{$\operatorname{Expt} 2^{\prime \prime}$} & \multicolumn{2}{|c|}{ Expt $1^{i}$} & \multicolumn{2}{|c|}{$\operatorname{Expt} 2^{r}$} \\
\hline & & & 30 & 60 & 30 & 60 & 30 & 60 & 30 & 60 \\
\hline 0 -hr & & - & 585 & 795 & 615 & 812 & 1080 & 1800 & - & - \\
\hline- & & 0 -hr & 640 & 1000 & 675 & 1054 & 2660 & 4780 & - & - \\
\hline 0 -hr & + & $0-\mathrm{hr}$ & 1100 & 1780 & 1555 & 3989 & 10050 & 19700 & 一 & - \\
\hline 12-hr & & - & 510 & 625 & - & - & - & - & - & - \\
\hline - & & $12-\mathrm{hr}$ & 1360 & 2400 & 1325 & 2385 & 1365 & 2400 & - & 一 \\
\hline $12-\mathrm{hr}$ & + & $12-\mathrm{hr}$ & 4425 & 7950 & 5520 & 9926 & - & - & 5500 & 10550 \\
\hline 0 -hr & + & $12-\mathrm{hr}$ & 11350 & 20060 & 9205 & 18331 & 10800 & 20400 & 7430 & 14300 \\
\hline $12-\mathrm{hr}$ & + & 0 -hr & 650 & 930 & 950 & 1690 & - & - & 7500 & 14100 \\
\hline
\end{tabular}

"The reaction mixtures and conditions were as described in Table I except that $300 \mu \mathrm{g}$ of cysts S-105 proteins (see Fig. 1) were added as the source of enzymes and factors. The background values $(0$-hr reaction) were subtracted in all cases.

${ }^{n}$ The amount of $40 \mathrm{~S}$ and $60 \mathrm{~S}$ subunits used was 0.44 unit $\left(A_{280}\right)$ and 0.70 unit $\left(A_{260}\right)$, respectively.

The amount of $40 \mathrm{~S}$ and $60 \mathrm{~S}$ subunits used was 0.22 unit $\left(A_{260}\right)$ and 0.35 unit $\left(A_{260}\right)$, respectively.

system. Also, in the untreated group (control) $60 \mathrm{~S}$ subunits from 0 -hr cysts are much less active than $60 \mathrm{~S}$ subunits from $12-\mathrm{hr}$ embryos, whether they interact with $40 \mathrm{~S}$ subunits from 0 -hr or 12 -hr embryos. In contrast, $40 \mathrm{~S}$ subunits from 0 -hr embryos are more active with $60 \mathrm{~S}$ subunits from 12-hr embryos than are $40 \mathrm{~S}$ subunits from 12 -hr embryos with $60 \mathrm{~S}$ subunits from 12-hr embryos. The reason for that latter finding is still not clear but it may be due to contamination of the 12 -hr embryo $40 \mathrm{~S}$ subunits with RNase (30). However, it is important to note that filtration of the 0 -hr embryo ribosomal preparation through Sepharose $6 \mathrm{~B}$ (in the presence of $100 \mathrm{~mm}$ $\mathrm{KCl})$ prior to dissociation of the ribosomes and subunit isolation eliminates the inhibitory component associated with the $60 \mathrm{~S}$ ribosomal subunit, irrespective of the method used for ribosome purification. Addition of the S-105 fraction inhibitor (A) to Sepharose 6B-treated cyst ribosomes also reduces the translational efficiency (data not shown). Whatever the nature of the ribosome-associated inhibitor, it is similar both chemically and functionally to the inhibitor found in the S-105 fraction from $0-\mathrm{hr}$ cysts described earlier in this paper. We conclude that the low proteinsynthesizing activity of $80 \mathrm{~S}$ ribosomes from undeveloped $A$. salina embryos compared to ribosomes from later stages of development is due primarily to nonfunctional, metabolically repressed $60 \mathrm{~S}$ subunits.

\section{DISCUSSION}

Various aspects of protein synthesis have been studied extensively in sea urchin embryos and in other species, yet very little is known about the mechanism which controls protein synthesis during embryonic development. It appears, however, that protein synthesis is controlled at the translational level during early development (1). Using encysted embryos of the brine shrimp, A. salina, several investigators have demonstrated that large quantities of $80 \mathrm{~S}$ ribosomes are present in the cysts and that these ribosomes readily dissociate into their $60 \mathrm{~S}$ and $40 \mathrm{~S}$ subunits on treatment with high concentrations of $\mathrm{KCl}(9,33)$. The ability of ribosomes to dissociate in the presence of high concentrations of monova- 
lent cations has been used as a criterion for ribosomes which are quiescent in protein synthesis, since ribosomes actively engaged in protein synthesis (as polysomes) are resistent to dissociation by monovalent cations $(31,32)$. The finding that ribosomes from $A$. salina cysts dissociate completely in the presence of $700-1000 \mathrm{~mm}$ $\mathrm{KCl}$ is consistent with the criterion for "inactive" ribosomes and supports the hypothesis that ribosomes from undeveloped eggs or embryos have a low efficiency in supporting protein synthesis $(7,15-17)$. The virtual absence of polysomes in $A$. salina cysts may be due, at least in part, to limiting amounts of functional mRNA (30), but the results presented in this study support the hypothesis that polysome formation is hindered by the availability of functional ribosomes.

Our findings indicate that only a small fraction $(10-20 \%)$ of the $80 \mathrm{~S}$ ribosome population from undeveloped cysts is active in protein synthesis using cyst enzymes and poly $(\mathrm{U})$ as template compared to the $80 \mathrm{~S}$ ribosome population from later embryos. As development proceeds the $80 \mathrm{~S}$ ribosome population becomes more efficient in its ability to translate poly(U), a finding consistent with the observations on polysome formation (in vivo) during development in A. salina $(5,7)$. Ribosomes purified by either the $\mathrm{KCl}$-washing method or DEAEcellulose method gave similar results. We interpret our data as indicating that a large fraction of the ribosome population of $0-\mathrm{hr}$ embryos is repressed metabolically.

Our findings regarding ribosome efficiency are in general agreement with those of Clegg and co-workers $(5,7)$. The discrepancy between our findings and those of Hultin and Morris (6) who reported that ribosomes from cysts and later embryos are equally efficient in supporting protein synthesis is probably due to the different methods used in purifying ribosomes. The ribosome-washing procedure employed by these investigators included sodium deoxycholate and probably stripped most loosely bound material from the ribosomes. The latter investigators also used a rat liver $105,000 \mathrm{~g}$ supernatant fraction as the source of enzymes and factors instead of a brine shrimp system as used in our investigation. Therefore, their ribosome and enzyme preparations may have been free of the regulators or inhibitors of protein synthesis of the type found by us in the brine shrimp system.

In some sea urchins it has been demonstrated that ribosomes isolated from unfertilized eggs are functionally repressed by a protein closely associated with the egg ribosomes (15-18). After fertilization or artificial activation of the egg the inhibitory protein is released or inactivated and the ribosomes regain full activity. From our investigation of the protein-synthesizing apparatus in $A$. salina, we have concluded that a large part of the ribosome population from cysts are metabolically repressed by a mechanism similar to that present in sea urchin eggs/embryos. Furthermore, our data indicate that the inhibitor is associated with the $60 \mathrm{~S}$ ribosomal subunit of the ribosome and that it is released or inactivated during development. The exact nature of the ribosome-associated inhibitor remains to be ascertained; however, preliminary evidence indicates that it is a heat-labile protein similar to that found in the cyst $105,000 \mathrm{~g}$ supernatant fraction. The association between the inhibitor and ribosome appears to be complex since the inhibitor is not readily dissociated from the ribosome by high concentrations of $\mathrm{KCl}$ unless the ribosomes are first passed through a column of Sepharose $6 \mathrm{~B}$ in the present of $100 \mathrm{~mm} \mathrm{KCl}$. Ribosomal subunits ( $40 \mathrm{~S}$ and $60 \mathrm{~S}$ ) obtained by this treatment are fully interchangeable irrespective of whether they were obtained from 0 -hr or 12-hr embryos.

We have found that the crude $105,000 \mathrm{~g}$ pellet, especially from developed embryos, contains RNase and protease activity but our results have indicated that these proteins are not responsible for the inhibitory activity associated with the $60 \mathrm{~S}$ subunit of cyst ribosomes.

During this investigation we observed that there is a close relationship between the efficiency of $A$. salina ribosomes to translate poly(U) and their ability to bind $\left[{ }^{14} \mathrm{C}\right]$ Phe-tRNA. Since the binding of acylated tRNA's to the ribosome occurs prior to 
peptide-bond formation, the efficiency of the system in translating mRNA should depend, at least to some extent, upon the ability of ribosomes to bind acylated tRNA's and to form stable and functional complexes. In the brine shrimp system it appears that the primary action of the inhibitor is to prevent formation of a stable ternary complex (80S-poly(U)-Phe-tRNA) such as that promoted by elongation factor EF-1. The findings of McCroskey et al. (11) which indicate that addition of $60 \mathrm{~S}$ subunits from $A$. salina cysts to an initiation complex causes the release of acylated tRNA's from the initiation complex are consistent with the present results. Finally, it should be noted that the brine shrimp protein-synthesis inhibitor was tested in an aminoacylation reaction and found to have no effect upon formation of $\left[{ }^{14} \mathrm{C}\right] \mathrm{Phe}$ tRNA.

The cellular and molecular mechanisms which operate in controlling protein synthesis in eukaryotes are not well understood. Some investigators have proposed that the rate of polysome formation in embryos depends primarily on the rate of release of functional mRNA from sequestered forms in the egg $(13,14)$. However, evidence is accumulating in support of the hypothesis that the rate of polysome formation in developing embryos as well as in other eukaryotic systems is regulated primarily by the availability of functional ribosomes $(15-18,34-36)$. It is our view that protein synthesis during development is regulated by several factors and that more attention should be focused on elucidating the mechanisms which sequester or activate mRNA and which repress or derepress ribosomes.

\section{ACKNOWLEDGMENTS}

We extend our appreciation to Dr. D. desSauges Thomas of the Department of Biology for his critical reading of the manuscript, and to $\mathrm{Dr}$. Severo Ochoa of New York University for making the results of his work on Artemia available to us before their publication.

\section{REFERENCES}

1. Gross, P. R. (1967) in Current Topics in Developmental Biology (Moscona, A. A., and Monroy,
A., eds.), Vol. 2, pp. 1-46, Academic Press, New York.

2. Epel, D. (1967) Proc. Nat. Acad. Sci. USA 54, $107-111$.

3. Epel, D., Pressman, G. C., Elsaesser, S., and Weaver, A. M. (1969) in The Cell Cycle: Gene-Enzyme Interaction (Padilla, G. M., Whitson, G. L., and Cameron, I. L., eds.), pp. 279-298, Academic Press, New York.

4. Golub, A., And ClegG, J. S. (1968) Develop. Biol. 17, 644-656.

5. Clegg, J. S., and Golub, A. (1969) Develop. Biol. $19,178-200$.

6. Hultin, T., and Morris, J. F. (1968) Develop. Biol. 17, 143-164.

7. Finamore, F. J., and Clegg, J. S. (1969) in The Cell Cycle: Gene-Enzyme Interactions (Padilla, G. M., Whitson, G. L., and Cameron, I. L., eds.), pp. 249-278, Academic Press, New York.

8. Rinaldi, A. M., and Monroy, A. (1969) Develop. Biol. 19, 73-86.

9. Zasloff, M., and OchoA, S. (1971) Proc. Nat. Acad. Sci. USA 68, 3059-3063.

10. Zasloff, M., and Ochoa, S. (1972) Proc. Nat. Acad. Sci. USA 69, 1796-1799.

11. McCroskey, R. P., Zasloff, M., and Ochoa, S. (1972) Proc. Nat. Acad. Sci. USA 69, 2451-2455.

12. Zasloff, M., AND OchoA, S. (1973) J. Mol. Biol. 73, 65-76.

13. Humphreys, T. (1969) Develop. Biol. 20, 435-458.

14. Denny, P. C., and Reback, P. (1970) J. Exp. Zool. $175,133-140$.

15. Hultin, T. (1961) Exp. Cell Res. 25, 405-417.

16. Monroy, A., Maggio, R., and Rinaldi, A. M. (1965) Proc. Nat. Acad. Sci. USA 54, 107-111.

17. Metafora, S., Felicetti, L., and Gambino, R. (1971) Proc. Nat. Acad. Sci. USA 68, 600-604.

18. Gambino, R., Metafora, S., Felicetti, L., and RaIsman, J. (1973) Biochim. Biophys. Acta 312, 377-391.

19. Ilan, J., and Ilan, J. (1971) Develop. Biol. 25, 280-292.

20. Peterson, E. A., and Sober, H. A. (1956) J. Amer. Chem. Soc. 78, 751-755.

21. Warner, A. H., and MCClean, D. K. (1968) Develop. Biol. 18, 278-293.

22. McClean, D. K., and Warner, A. H. (1971) Develop. Biol. 24, 88-105.

23. Dufresne, M. J., and Igarashi, S. J. (1972) Proc. Can. Fed. Biol. Soc. 15, No. 566.

24. Bagshaw, J. C., Finamore, F. J., and Noveldi, G. D. (1970) Develop. Biol. 23, 23-35.

25. LI, C. C., AND YU, C. T (1971) Biochemistry 10, 3009-3013.

26. Mans, R. J., And Novelli, D. (1961) Arch. Biochem. Biophys. 94, 48-53. 
27. Lowry, O. H., Rosebrough, N. J., Farr, A. L., and Randall, R. J. (1951) J. Biol, Chem. 193, 265-275.

28. Ogur, M., and Rosen, G. (1950) Arch. Biochem. 25, 262-276.

29. Okamoto, T., and Takanami, M. (1963) Biochim. Biophys. Acta 76, 266-274.

30. Huang, F. L. (1973) Ph. D. Dissertation, University of Windsor.

31. Martin, T, E., Rolleston, F. S., Low, R. B., AND Wool, I. G. (1969) J. Mol. Biol. 43, 135-149.
32. Zylber, E. A., and Penman, S. (1970) Biochim. Biophys. Acta 204, 221-229.

33. Hultin, T., Naslund, R. H., and Nilsson, M. O. (1969) Exp. Cell Res. 55, 269-274.

34. Salb, J. M., and Makcus, P. I. (1965) Proc. Nat. Acad. Sci. USA 54, 1353-1358.

35. Kay, J. E., Ahern, T., And Atkins, M. (1971) Biochim. Biophys. Acta 247, 322-334.

36. Barden, N., and Korner, A. (1972) Biochem. J. 127, 411-417. 